\title{
USING LITERATURE IN GEOGRAPHY LESSONS
}

\author{
ROXANA HOBAI \\ "Dr. Bernády György" Secondary School, Târgu Mureș, Romania, e-mail: roxana_ro2011@yahoo.com
}

(Received: August 2014; in revised form: October 2014)

\begin{abstract}
Including in a novel information about relief, climate, vegetation, fauna and various aspects of socio-economic life can make literature a real source of geographical information. Using realistic literary works in Geography lessons has multiple benefits, which are not limited only to geographical knowledge. In this paper there are some fragments from literature, suggestions of activities about how to integrate the fragments during Geography lessons and the results of these activities. The activities are from fifth to twelfth grade, passing through a first example of water pollution resulting from a Hercules labour, through the lyricism of the aurora borealis description, through the dramatic life of a refugee from Darfur, through the Dobrudgea winter landscape, through the grey urban landscape of Bucharest in the 90s and so on. Students were put into learning situations that stimulated their creativity, developed communication competencies and enriched their general knowledge.
\end{abstract}

Keywords: reading, realistic literature, literary description, geographical description, interdisciplinary

\section{INTRODUCTION}

In a period when the link between students and reading seems to be more and more fragile, the time for reading is increasingly limited and the number of bookstores decreases from one year the another, using literature to teach Geography seems to be anachronistic.

Why use literature to learn Geography? In a plea for the use of literature in Geography lessons, S. E. Hume gives the following answers: because there is a natural link between Geography and literature, because literature study improves Geography comprehension and because reading a 
book that includes geographical features facilitates the comprehension of the book in question (Hume, 1996).

The close links between Geography and literature are highlighted in a comparative analysis of American literature (from the USA) with the Canadian one. The analysis assumes that between them it should not be big differences, given the common language and the common historical experience regarding the detachment from the colonizing Europe. Despite these, the differences are remarkable, and they are caused exactly by the physical and geographical differences between the two countries (Mitchell, 1987).

Using literature in Geography lessons comes to support Romanian language and literature study as a subject matter. In Romania, at the national evaluation exams at the end of eighth grade, at Romanian language and literature evaluation, some of the competencies concerned are: "1.1. Proven understanding of a literary or non-literary text, starting from requirements" and "2.1. Writing different texts with different purposes and destinations, adapting them to the situation of direct communication" (according to the Exam Curriculum for Romanian language and literature, MEN, 2014).

In the structure of written exam, students have items such as: "Write a composition of 10-15 rows to describe an impressive picture of nature." (Subject II.B, June 2011, National Evaluation). The difficulties encountered by students in solving these subjects, apparently with a low degree of difficulty, can be also surmounted in terms of interdisciplinary approaches between Geography and Romanian language and literature. Through the use of literary texts in Geography lessons, students are helped in forming communication competencies in the Romanian language. In Geography lessons, students develop the competency to analyze and interpret images and aspects of reality using literary and scientific language (Dulamă, 2011).

The same author points out that literary readings are important because by reading, students acquire the ability to decipher the text, to understand the content, they develop the ability to receive information, to think, to evaluate the text message (Dulamă, 2000). By reading literature, students have the opportunity to notice how different aspects of reality are described by writers.

To support the use of literature in Geography lessons, I chose several novels to which I indicated the fragments that could be used during lessons. The examples used are given as a guide, meaning that a book can be used in lessons also in other ways than these shown here and also in different moments of the lesson, and the list of the methods used in applying these fragments can be extended. 


\section{METHOD}

\section{Participants}

In this research were involved students from the $5^{\text {th }}$ to the $8^{\text {th }}$ grade from "Dr. Bernády György" Secondary School and students from the $9^{\text {th }}$ to the $12^{\text {th }}$ grade from "Unirea" National College, Târgu Mureş. Students perceived me as a teacher, not as a researcher.

\section{Procedure}

In different moments of the Geography lessons, like meaning realization, knowledge achievement and reflection, I presented to the students short fragments from various novels. Based on these, for the development of geographical knowledge, I built a dialogue, in which I used the ideas from literature fragments. Starting from these texts, students solved various tasks in class and as homework.

\section{Activity 1. The $5^{\text {th }}$ Grade}

Subject: Hydrographical elements of the local horizon

In forming competency "8.1. Identification of environmental protection solutions for the local or the nearby horizon" (MEN, Geography Curriculum), discussions on water pollution are needed. The discussions started from one of the first examples of water pollution that appears in literature, precisely in "The Legends of Olympus" by Al. Mitru. One of the twelve labours of Hercules was cleaning Augias stables, stables with over 300 cattle, which had not been cleaned for over 30 years. To fulfil the task, Hercules diverted the Alpheus and the Peneus rivers so that they flowed through the stables and cleaned them up.

The fragment from the novel, which was used in the lesson, was the following:

"And Hercules went to king Augias, to fulfil the command.

- King Eurystheus sent you for a year, said Augias, seeing Hercules. I believe that not even in a lifetime you would succeed to clean my stables. $[\ldots]$

- What would you say if, for example, I could clean all the garbage from the stables in a single day, and not in a lifetime? [...]

He hit forcefully the high wall, from the back of the stables, making two breaches. In front of each breach made in the wall, he dug a channel, towards the two nearby rivers: the Alpheus and the Peneus.

Water entered in the channels, then, through the breaches, in the Augias stables. [...] Water entered through the bottom of that huge stable and flowed to the front, carrying all the garbage. 
It was not even evening, and Augias stable was clean, and the breaches from the wall were sealed. The Alpheus and the Peneus were flowing back in their riverbeds, and the new canals, filled with earth, not even recognizable." (Mitru, 1998, p. 42).

\section{Activity 2. The $6^{\text {th }}$ Grade}

\section{Subject: France}

The fragments about "Paris", by Matteo Merzagora and Sylvie Coyaud, come from a tourist guide.

As it is written in the style of a literature book, it can be a reading for someone who reads it without necessarily pursuing the purpose of sightseeing the city. The fragments were used to support the formation of competency "2.1. Identification of names and terms from the Geography of Europe in foreign languages" (MEN, Geography Curriculum).

"... how much trust in the universal gravitation had the engineer who designed it! Here's what you can build by assumptions, here's the rope made of iron, which Fakir tossed skyward and inviting his friends to climb ..." (Giraudoux Jean, 1927, quoted in Merzagora, Coyaud, 2007, p. 84).

"The white silhouette [...] is shining on the Parisian panorama almost like a detergent advertising: from time to time, when you least expect, behind the corner, outlining in the sky, shining and basking in the sunshine. One cannot understand why smog darkens all the monuments except this one [...]". (Merzagora, Coyaud, 2007, pp. 170-171).

"If you arrive in front of it [...] you will not see anything because hundreds of people already irritated by the queue, push and irritate, in turn, a platoon of guards. The guards, zealous, pull out the cameras from the unruly tourists who do not respect any warning prohibiting photography, nor their neighbours whom they returned elbows and pushing. [...] And she [...], laughs." (Merzagora, Coyaud, p. 177).

"When it was finished, in 1977, Parisians were in front of something they had not seen in their city before: it was all inside out, with pipes and ladders out and painted in all colours! Some cried out: what a monster! [...] Others came running [...] up the stairs to the exterior mobile stairs from the transparent bowels of the building [...]." (Merzagora, Coyaud, 2007, p. 180).

\section{Activity 3. The $7^{\text {th }}$ Grade}

Subject: the United States of America

For forming competency "6.1. Explaining the importance of the geographical environment for man and society from extra-European continents" (MEN, Geography Curriculum), I used a fragment from "The Grapes of Wrath" by John Steinbeck. This fragment was used in a discussion about the 
importance of agriculture for the USA and the difficulties faced by the agriculture of this country until it reached the current high efficiency.

"When the night came it was as dark as pitch, for the stars could not pierce the dust to get down to the earth, and the window lights could not even spread beyond their own yards. Now the dust was evenly mixed with the air, forming an emulsion of dust and air. The houses were locked and people were stuffing clothes through the cracks of doors and windows, but the dust still came in, a fine powder that could not be seen in the air, sitting like pollen on chairs, tables and dishes. The people brushed it from their shoulders. [...]

[...] In the morning the dust hung like fog, and the sun was red and fiery like fresh blood. All day the dust sifted down from the sky, and it was the same the next day." (Steinbeck, 2013, pp. 72-73).

\section{Activity 4. The $8^{\text {th }}$ Grade}

Subject: The climate

The following fragment from "Uruma" by Zaharia Stancu was used at the chapter "The climate" for highlighting climate influences manifested in the Dobrudgea Plateau, in support of forming the competency "1.1. Recognition of geographical terms in different texts" (MEN, Geography Curriculum).

"After a month the winter arose as a huge white bear, sitting down on all fours, grumbling and gasping between its teeth and lips.

Irritated by this fumbling, the whistling snakes of huge snowstorms were rushing in whirlwinds over the frozen Dobrudgea. Between sky and earth, from one horizon to the other, the snowstorms scattered and stirred the immaculate snows. [...]

Badgers were sleeping hidden in their dens.

Fat bustards were hiding in snow drifts high as a house.

Rabbits with naive eyes and forever pricked ears were gnawing the small hip rose bushes from the baulks. [...]

The roads, [...], were mastered by packs of hungry wolves. [...]

On the chimneys of the shepherd huts, on that of the Turkish and Tartar huts, black wisps of smoke were rising.

The Dobrudgea people [...] were hibernating.

Only the sea was alive, black and unimaginable wild." (Stancu, 2010, pp. 101-102).

\section{Activity 5. The $9^{\text {th }}$ Grade}

Subject: Composition and structure of the atmosphere 
In the activity of identifying the characteristics of each atmospheric layer, on the subject "Composition and structure of the atmosphere", in order to characterize the thermosphere, I used a fragment from the well-known novel "Fram, the Polar Bear", by Cezar Petrescu. This approach was to support forming the competency "1.1. Using scientific and characteristic terminology for this discipline (concepts, definitions) for the presentation of relevant information." (MEN, Geography Curriculum).

"After the first blizzards of winter, the sky suddenly cleared out of clouds. [...]

The night vault unveiled high and blue, with sparkling stars. [...]

Sometimes, the moon was bathing the white infinity with pearl sheen. [...] Other times, only the stars were sparkling.

Then it waved, on half of the sky, aurora borealis.

First three rainbows with all known and unknown colours appeared. They melt one in each other. They separated and then they joined again. And in their mysterious arch on the sky, the lights started to flicker in a trembling and fantastic game. Blue, red and green, violet and orange, yellow and soaked in purple, the flames were weaving and flowing in silk hangings, they were unfolding and touching unexpectedly.

For a moment the sky was clear.

And then again the magic ring dance started again.

Small lights were sparkling, like in a Christmas tree. Tinsel threads were fluttering. Myriads of sparkles were bustling. And all was recreating soon afterwards under the arched rainbow, in a translucent curtain, in which the blue and red, violet and green, yellow and orange lights were sliding." (Petrescu, 2005, p. 106).

\section{Activity 6. The $10^{\text {th }}$ Grade}

Subject: The main current issues of Political Geography

"The Translator" by Daoud Hari is a novel about his memories of Darfur. The fragment was used at the topic "The main current issues of Political Geography", in support of forming the competency "1.1. Using scientific and Geography characteristic terminology in order to present information regarding Political Geography" (MEN, Geography Curriculum).

"Darfur is the place where I lived with my family until the attack on our village. Our tribe is called the Zaghawa. We are traditional herdsmen who lived in permanent villages; our grass huts are very big around and have pointed roofs that smell very good when it rains. My childhood was as full of happy adventures as yours. You probably had a bicycle and then a first car; I had a camel, Kelgi, that I loved very much and I was running like the wind with my camel. [...] 
Hundreds of thousands of people from my tribe were killed recently. Between the others, two and a half million are now living difficult lives in refugee camps or in solitary hiding places in desert valleys." (Hari, 2009, p. 9).

"[...] the Arab government of Sudan, because they wanted settled people off the land, was taking sides with the Arab nomads and provided them with guns, helicopters, bombers and tanks to decide the arguments. Because of this, many of the young Zaghawa went to join resistance groups." (Hari, 2009, p. 24).

"It is unbelievable in how many ways people can be hurt and killed, in how many ways villages can be terrorized and burned, in how many ways children can die in deserts, and young mothers put in sufferance." (Hari, 2009, p. 87).

\section{Activity 7. The $11^{\text {th }}$ Grade}

Subject: Natural and anthropogenic hazards

For the subject "Natural and anthropogenic hazards" I used a fragment from the novel "Tuareg", by Alberto Vázquez-Figueroa, in support of forming the competency "2.4. Explaining the observed relationships between natural and human systems of the environment" (MEN, Geography Curriculum). The writer, inspired by the period in which he lived together with Tuaregs, described how they exploited the invasions of the locusts:

"Whether if the legend was true or not, that was the behaviour of the locusts, but the Tuaregs, $[\ldots]$, had solved their hunger issue in a much more practical way, choosing to eat the insects in the same way the locusts were eating their crops [...]. Roasted on coals or turned into flour, the locusts become one of their favourite foods and when they arrived in millions, blacking out the sun at midday, it wasn't for them an image of misery, but one of prosperity and abundance for many months. Over three years they would come back and Laila would turn the insects into flour, which mixed with honey and dates would be a treat for children.

He loved those cookies and he missed the long dusk hours, when he was sitting at the entrance in his tent, eating a piece of cookie and watching the sun slipping below the horizon and drinking a cup of hot tea" (VázquezFigueroa, 2005, p. 275).

\section{Activity 8. The $12^{\text {th }}$ Grade}

Subject: The system of European cities. Geographical analysis of some cities

The following fragment from "Stories from the Exile" by Neagu Djuvara was used to characterize Bucharest city, in forming the competency "1.1. Written and spoken presentation of the defining aspects for European and national space, using correctly and coherently the characteristic terminology for the area" (MEN, Geography Curriculum). In order to emphasize the 
capital city transformation during the communist regime I showed to my students how the author found the capital city, when he was returning home after a long period in exile.

"Beside the few buildings destroyed, burned or riddled with bullets in the days of December, the centre was unchanged; I was finding myself at home, only that the buildings seemed unpainted for decades. But the new districts gave Bucharest a completely different physiognomy, with long boulevards with almost identical buildings, with not disgraceful architecture, if it wouldn't be the poor quality construction material. The rain has left long grey traces on all fronts; fifteen to twenty years old houses seemed like a hundred years old. [...] I had a wrench to discover that a large European capital could keep millions of people in such a primitive urban level. [...] I could not imagine that in Europe it might be such a rude quality and aesthetical level.

Even more serious and more surprising to me [...] it was the appearance of the street, the physiognomy of the passers-by. Don't tell me that I was perhaps the victim of the memory deformation of a childhood imagine, because I was twenty-eight years old when I accidentally left the country. No. People on the street looked different, there were others. I felt the ethnic profile of the Romanians was changed. The faces appeared to me swollen, darkened, like there were drunken people. No one was smiling on the street." (Djuvara, 2005, pp. 457-458).

\section{Data collection and research material}

For data collection I used the observation method. I recorded in a protocol of observation and analyzed students' opinions, students' and teachers' questions and answers about the content of the fragments in the novel.

\section{RESULTS AND DISCUSSIONS}

\section{Activity 1. The $5^{\text {th }}$ Grade}

After the fragment from the "The Legends of Olympus" by Alexandru Mitru was read aloud by the teacher, this moment was followed by a dialogue between teacher and students. The students verbally answered to questions from the teacher, such as: "How did Hercules change the natural environment" ("He diverted the rivers."), "Why did he divert the rivers?" ("To clean the stables."), "What was the source for the water pollution?" ("Animal husbandry."), "What are the positive consequences of the act of Hercules?" ("He cleaned the stables.") "What are the negative consequences?" ("He polluted the rivers."), etc.

The activity showed students' particular receptivity when they were told a story. Their attention is easy to captivate and students are even more 
open because a very popular character and one of the best known books. The discussion can be easily extended to a current theme on present water pollution in the local horizon.

This fragment incited the interest of all students, both those who read "The Legends of Olympus" and those who did not, but they said that they would read it, under the impulse given by to use of this fragment in the Geography lesson.

\section{Activity 2. The $6^{\text {th }}$ Grade}

The fragments from the tourist guide of Paris were used on the topic "Economic activities", in the discussions about tourism in Europe. I wanted to identify some famous Parisian landmarks, with the help of my students.

The teacher read aloud the fragment and students had 30 seconds in order to write in the notebook the names of the presented tourist attractions; at the fourth landmark, students were warned that it is about a painting and they had to identify both the name of the painting and the place where it is exposed. Thus, they have identified the Eiffel Tower, Sacré-Coeur basilica, Centre "Georges Pompidou" and the painting "Mona Lisa" by Leonardo da Vinci, displayed in the Louver.

All students easily identified the Eiffel Tower and the painting "Mona Lisa", 85\% identified the Louver Museum, 75\% identified Sacré-Coeur and only $10 \%$ identified the "Pompidou" Centre. Despite the fact that students had the greatest difficulty in identifying the "Pompidou" Centre, the description from the read fragment made them very curious to find out about which Parisian landmark we were talking about.

At the end of the lesson, questioned about the impact of using these texts, students had positive feedback: they loved it because they "learned about a new tourist attraction", because they "recognized the places", because the "recognition was not based on common questions, but on some texts", because they had "the impression that it was a game in which I addressed them geographical riddles", etc.

\section{Activity 3. The $7^{\text {th }}$ Grade}

"The Grapes of Wrath" by John Steinbeck is one of the novels that can be used both in Geography and history lessons. This novel can support approaches to teach about the Dust Bowl that affected the USA in the 1930s (causes, manifestations, and consequences) and also to teach about farmers' migration from Oklahoma westward to California's fertile lands.

I used the Dust Bowl fragment at the eighth grade in the lesson "The United States of America". This fragment can be used also in the eleventh grade at unit "Environmental Degradation and Protection". Fragments about migration can be used in the tenth grade, on the topic "Population's Territorial Mobility". 
Among the ways in which this fragment can be used, I chose to use it in a moment of reflection, at the end of the lesson. After listening to the fragment, students had three minutes, while they were asked to write a question on a piece of paper, a question that they would like to address to the author of the fragment. I collected the notes and in the next Geography class I answered the most interesting questions. In this case, the reading was supported with appropriate images with the Dust Bowl.

The students' questions showed that the reading and the images arose their curiosity and interest for the subject. They were curious to ask the author if he "really lived that moment", if they "could go to school in that period", if "there was so much dust in the air", "what were the causes that generated the dust storms", "what could we do to make this phenomenon not occur for the second time", if "there were possibilities that such a phenomenon might be produced even in our country", etc.

\section{Activity 4. The $8^{\text {th }}$ Grade}

At the end of the chapter "The climate", in a sequence of time dedicated to the revision of this chapter, each student received a worksheet on which it was also written the fragment that was to be analyzed (from "Uruma", by Zaharia Stancu). After I read aloud the fragment, students had a few minutes to solve the tasks in the worksheet.

The worksheet included questions about geographical information comprised in the fragment: "Why the blizzards are frequent in the Dobrudgea Plateau?" ("because of the Eastern European climate influences"), "How do you explain that nowadays quite rarely we encounter situations in our country when the snow drifts are high as a house?" ("because of global warming"; "the wind blows away the snow and gathers it behind obstacles"), "About what animals do we read in the fragment?" ("bustards, badgers, rabbits, and wolves"), "Which of these species no longer exist today in Dobrudgea?" and "Specify the cause of this fact." ("bustards are missing because of excessive hunting"), "Where have you found out, during this school year, features of the Black Sea as they are presented in the fragment studied today?" ("when we discussed about the name of the Black Sea, which originally was called Pontus Euxinus, meaning Inhospitable Sea"), "What are the ethnic groups mentioned in the text?" ("the Tatars and the Turks"). In the topics about our country's ecosystems and ethnic structure of the population, I evoked this fragment.

\section{Activity 5. The $9^{\text {th }}$ Grade}

Although the novel "Fram, the Polar Bear" written by Cezar Petrescu, that belongs to children's literature, is not among realistic novels as other novels mentioned in this paper, I used a fragment from this novel to describe the aurora borealis. 
When I read the fragment aloud, after the sentence "Then it waved, on half of the sky, ...", I made a pause and I asked the students to name the geographical phenomenon that was happening. Then one of the students read the fragment aloud. After reading the text, with the help of students and with a sketch drawn on the board we discussed the formation of Polar auroras.

Based on this fragment, students received as homework to write a story entitled "A Day Beyond the Northern Polar Circle", in which to imagine they were on a trip near the Polar Circle and they spent there one night and they saw the aurora borealis. Students were invited to include in the story a postscript with the impression they had about this activity developed in the class and continued at home. Among their views, some were impressed by how the phenomenon took place and there were some students who said they would like to go on a trip to see with their own eyes the aurora borealis.

\section{Activity 6. The $10^{\text {th }}$ Grade}

Reading the fragment from "The Translator" by Daoud Hari was used in an evocative and motivation moment, in the preamble on the topic "The main current problems of Political Geography". Based on the fragment, they discovered information such as: the name of the region which was in conflict with Sudan (Darfur), one of the reasons why there were conflicts in that area (ethnic and religious reasons), the difficulties that non-Arab population was facing (living in refugee camps or being isolated in desert areas). Using the information already achieved by students from their general knowledge or from the previous lesson ("The evolution in time of the political map of the world"), we discussed the role held by the colonizing powers in generating these conflicts.

Working in teams, the students imagined an interview that a reporter would take to a refugee from a conflict area; one of the two members of the team was the reporter and the other was the refugee. By making such an interview, students developed their capacity to formulate and ask questions about a particular situation and to make an explicit presentation of a geographical event (Dulamă, 2008). Through survey, three interviews were presented in front of the classroom. Among the questions raised by students there were: "What is your religion?", "Where is now the rest of your family?", "How old were you when you were separated from your family?", "How does your school look like?", "How can you provide food?", "Does anyone in your family work?", etc.

At the end of the lesson, students had the task to write on a piece of paper, for a minute, what impressed them the most about the lesson of the day. From their written messages, I noticed that students were impressed that "these days, in the world, there really are conflicts", that "although we live in peace, other people are permanently living in fear of war" and there were students who wanted to read the novel to learn more about the conflict described. 
The use of this fragment was followed by a homework assignment like an essay on the consequences of the conflicts on the population in the affected areas.

\section{Activity 7. The $11^{\text {th }}$ Grade}

The fragment from "Tuareg" by Alberto Vázquez-Figueroa was used at the topic "Natural and anthropogenic hazards", where, in addition to the negative consequences of hazards, there were identified ways of partial compensation of these negative effects. In case of locusts invasions, these were turned into flour and consumed as a valuable source of protein for the residents of desert and semi-desert areas. Starting from this example, I gave students the task to identify other effects that hazards might have, effects that, at some point, can be used to the benefit of people.

A brief oral survey among students about the impressions left by this fragment showed that they were impressed that "a negative environment feature can have its advantages", that "when you lived in a hostile environment, like the desert, this made each environment element to be valued, including locusts", by the fact that "the Tuaregs from the novel were forced, in absence of food, to eat locusts".

\section{Activity 8. The $12^{\text {th }}$ Grade}

The fragment from "Stories from Exile" by Neagu Djuvara was read aloud and then there were discussions with the students about the main ideas of the fragment. Comparisons were made between other cities which we have discussed previously (London, Paris, Rome, and Madrid) and Bucharest, in terms of the issues encountered in the read fragment: the aspect of the buildings, the architecture, how were the buildings taking care of, how the aspect of the city reflected the economic development, people's behaviour and their lifestyle. Many students travelled abroad so that they could directly observe these differences. We discussed the reasons that made not only Bucharest, but most of the cities from our country have such features.

At the end of the lesson, students were given the task, for three minutes, to reply in writing, on a piece of paper, to the question: "Did the fragment impress you? Give reasons for your answer." Their responses showed that students were aware of the implications of the communist regime on the appearance of cities, that they knew the consequences of forced urbanization that took place in our country, that although they were familiar with the issues in the fragment, because all our life we spent it in such an urban landscape it became something usual for us, and we did not realize that Romanian cities could look much better. 


\section{CONCLUSIONS}

Using realistic literature in Geography lessons has primarily "geographical" benefits. If in a novel is included information about relief, climate, vegetation, fauna and various aspects of the socio-economic life, then literature can be a real source of geographical information.

Under the impression that they read a fragment from a book that is not included in the scientific literature, therefore it requires a lower level of concentration, students can easily retain some geographical details. The reading moment is perceived by students as rather one of relaxation and with no obligation to retain the issues presented in the text.

The views expressed by students after these activities showed that they were impressed by the manner in which geographical phenomena were described, by how the urban landscape of Bucharest, the locusts invasions, aurora borealis, etc. were viewed through writers' eyes, and not researchers'. Stimulating students creativity and imagination was proved by the questions they addressed in the imaginary interview between a reporter and a refugee, by the questions they asked the author of the novel that described the Dust Bowl, etc. In addition, students expressed their desire to read all the novels from which the read fragments were extracted.

The links between Geography as a science and literature, as a form of presentation of some geographical information, led to the conclusion that using literature fragments in studying Geography had also other benefits, such as: ensuring an interdisciplinary approach between the study of literature and Geography, development of Romanian language communication skills, development of the capacity to understand a read text, improving general knowledge and creative interpretation of geographical phenomena, cultivating the taste for reading and for spending quality time in the literature companion.

Through geographical reading during the Geography lessons or outside the school, students read about inaccessible areas that could not be learnt through direct contact and they had access to subtler realities than those described in textbooks and scientific papers.

\section{References}

Daoud, H. (2009). Translatorul. Amintirile mele despre Darfur. București: Editura Allfa. Djuvara, N. (2008). Amintiri din pribegie. Bucureşti: Editura Humanitas.

Dulamă, M.E. (2000). Elemente din didactica geografiei. Cluj-Napoca: Editura Clusium. Dulamă, M.E. (2008). Metode didactice activizante. Cluj-Napoca: Editura Clusium. 
Dulamă, M.E. (2010). Fundamente despre competenţe. Cluj-Napoca: Editura Presa Universitară Clujeană.

Hume, S.E. (1996). Using Literature To Teach Geography in High Schools. ERIC Digest. ERIC Clearinghouse for Social Studies/Social Science Education, Indiana University.

Merzagora, M., \& Coyaud, S. (2007). Parisul. Bucureşti: Editura Erc Press.

Ministerul Educaţiei Naţionale, Centrul National de Evaluare şi Examinare (2011). Evaluarea Naţională pentru elevii clasei a VIII-a, Proba scrisă la Limba şi literatura română. www.edu.ro.

Ministerul Educaţiei Naţionale, Consiliul Naţionale pentru Curriculum. Programele şcolare, Geografie, clasele V-XII. www.edu.ro.

Ministerul Educaţiei Naţionale. Programa de examen pentru disciplina limba şi literatura română, Anexa nr. 2 la OMEN nr. 4431/29.08.2014 privind organizarea și desfășurarea evaluării naționale pentru absolvenții clasei a VIII-a în anul școlar 2014 - 2015. www.edu.ro.

Mitchell, K. (1987). Landspace and literature. In W., E. Mallory, \& P. SimpsonHousley (Eds.), Geography and literature, a meeting of the disciplines, New York: Syracuse University Press.

Mitru, Al. (1998). Legendele Olimpului, vol. II. Bucureşti: Editura Vox.

Petrescu, C. (2005). Fram, ursul polar. Bucureşti: Editura Cartex 2000.

Stancu, Z. (2010). Costandina. Uruma. Ce mult te-am iubit. Bucureşti: Editura Litera.

Steinbeck, J. (2013). Fructele mâniei. Iași: Editura Polirom.

Vázquez-Figueroa, A. (2005). Tuareg. Iași: Editura Polirom. 